greater share in the financial burden than they have in the past.

Following the submission of M. Blondel's report, Dr. N. R. Junner proposed that a tectonic and mineralogical map of Africa should be prepared, and M. Blondel, on being asked, generously undertook this additional task, which should fulfil a want long felt by many African geologists.

Prior to the meeting, the Association had invited the various geological services in Africa to prepare descriptions of the regions for which they were responsible, and in almost all cases this invitation was accepted. During the meeting brief summaries of these contributions were given, covering the following extensive territories: French Morocco, Sahara, Libya, Egypt, French West Africa, Portuguese Guinea, the British Colonies, French Equatorial Africa, Western Belgian Congo, the Katanga, Angola, Northern and Southern Rhodesia, the Union of South Africa and South-West Africa, Madagascar. These papers present an excellent review of African geology in 1948, and it is hoped that they will all appear in due course in the Comptes rendus of the Congress.

A geological bibliography of Central Africa, with additions to 1944 , recently published by Belgium and the Belgian Congo, was presented to the Association.

The Association had proposed for discussion a number of general subjects, most of which concerned the correlation of the older formations for the purposes of the International Map. A discussion on the Pre-Cambrian formations was opened by Prof. A. Holmes, who, on the basis of recent researches on the age determination of rocks by radioactive methods, and of the disposition of the different orogenic zones, suggested a number of correlations, which in some cases were at variance with those generally accepted. These views stimulated a most interesting discussion, in which many members of the Association took part.

There followed a discussion on the correlation of the Karagwe-Ankolean, Kavirondian, and Nyanzian formations of East and Central Africa, which again elicited much interesting information from many speakers. It was finally agreed that on the International Map these three formations should be shown by the samo colour, but with different symbols. The correlation of the Akwapimian, Birrimian and Buem formations was vigorously discussed by West African geologists, and it was finally agreed that the legend should show the upward succession long adopted by the Gold Coast Geological Survey, namely, Birrimian, Tarkwaian, Akwapimian, but with a note that certain French geologists would place the Akwapimian much lower. The Buem was to be shown as Upper Pre-Cambrian, but with the reservation that it might be Cambrian.

Following a discussion on the age and correlation of the Upper Kundulungu and the WaterbergMatsap, it was agreed that, on the map, these formations should be represented by one colour, and that in the legend the age should be left open, with the observation that the ages suggested by various geologists ranged from pre-Silurian to Devonian and even Carboniferous.

The value of African tillites for correlation purposes was discussed, as was also the importance of Stromatolites and comparable organisms in determining the age and relations of the older formations. It was at length agreed that owing to the lack of knowledge of the structure of these algal forms, they should be the subject of study by specialists; and on the motion of M. A. Jamotte, it was resolved that the International Palæontological Union should be invited to undertake a special study of them.

An extra meeting was devoted wholly to the problem of rift valleys, and following papers by Prof. R. M. Shackleton, Dr. R. B. MeConnell and Mr. A. M. Quennell, a valuable and interesting discussion took place, in which many members participated.

A long discussion was devoted to the terminology of the African Pleistocene, and it was finally agreed to recommend the adoption of the resolution on this question by the African Pre-History Conference held at Nairobi in January 1947. A resolution was also passed recommending the formation of a subcommission to study the distribution and correlation of the Kalahari Sands.

The question of the distribution, ages and origin of the African carbonatites also gave rise to a useful discussion.

Finally, during the last meeting of the Association, thirty-three porsonal contributions on the geology of the various territories of Northern, Central, Eastern and Southern Africa were noted, and certain of them briefly discussed.

It may be of interest to add that at a Specialist Geological Conference arranged in September by the British Commonwealth Scientific Organisation, in consequence of the presence in London of the delegates to the International Geological Congress, a discussion took place on the question of the formation of regional bureaux for the study of long-term fundamental research on African geological problems on a regional as distinct from a territorial basis.

This session of the Association of African Geological Surveys not only enabled many old personal contacts among African geologists to be renewed, but also led to many new ones; and the papers and discussions were of great interest and value not only because of the new observations revealed by them, but also on account of the stimulus they gave to international co-operation in the realms of geology and to a regional approach to many fundamental problems.

The Association recorded its appreciation of the invaluable services of its secretary, $M$. Blondel, not only in the successful organisation of the session, but also in co-ordinating the activities of the Association during the interval between the sessions of the Congress.

\section{POWER SUPPLY AND THE ELECTRICAL ENGINEER}

$\mathrm{T}$ HE title "Means and Ends" given to the presidential address of Mr. T. J. N. Haldane to the Institution of Electrical Engineers on October 7 expressed at once the twofold character and the unity of his subject. An eloquent reaffirmation of the faith of the engineer in the ultimate value of his calling was made by Mr. Haldane in the second part of an address which in the factual sphere concerned itself with the position of electricity power supply in Great Britain and Western Europe.

Pointing out that as early as the beginning of the seventeenth century Francis Bacon had indicated that man's mental and material progress are inseparably linked with one another, Mr. Haldane said, "At present it is all too painfully obvious that for most of the world we are very far from having 
achieved even that modest level of material prosperity such as would provide reasonable conditions for widespread spiritual development, which must, I believe, be regarded as our ultimate objective. So there remains a vast task for the scientist and engineer, whose work should receive whole-hearted approval, provided the raising of standards of life is regarded as a means rather than an end in itself." It was against this philosophic background that $\mathrm{Mr}$. Haldane reviewed the position of electricity supply in Great Britain and in Western Europe.

Referring first to the nationalization of this industry in Britain, and remarking that we might well be proud of the way in which the change to public ownership had been accepted, Mr. Haldane expressed satisfaction at the new British Electricity Authority's keen awareness of the special problems resulting from the unification of this great undertaking. The twenty years of successful operation of the Central Electricity Board engendered confidence in the future of the new Authority.

Mr. Haldane first gave a brief review of the broad economic position, in which he referred to the importance to the electrical export trade of cooperation of the British Electricity Authority with manufacturers so as to ensure that plant developed for home use should also be suitable and competitive for export, and he also mentioned the not inconsiderable part played by the independent consulting engineer in fostering British trade abroad. He then gave detailed consideration to power resources, drawing a clear distinction between the requirements for power and requirements for energy. Mr. Haldane commented on the important contribution which could be made by water-power schemes towards the meeting of peak loads. Any given water-power scheme will be limited to a certain average annual output of kilowatt-hours; but it is possible to install a large amount of plant and make a correspondingly large contribution to the peak-load problem at the expense of a reduced annual load factor. One of the existing hydro-electric schemes, the Galloway development, was designed for an annual load factor of about 20 per cent; and for the new Sloy station on Loch Lomond the designed load factor was only 10 per cent. Tidal schemes and large-scale windgeneration, because of the intermittent character of their supplies, could make little contribution towards meeting peak loads but could add appreciably to the total output of energy. "Intermediate between the two extremes of pure kilowatts and pure kilowatthours," he said, "comes the gas-turbine, burning oil, whose importance is mainly as regards kilowatts, with a contribution to kilowatt-hours limited by economic considerations. Gas-turbines permit the cheap provision of kilowatts, but, until coal can be used in place of oil, cannot be justified for load factors above about 10 per cent or 15 per cent. No doubt, nuclear fission, if and when used for power production, will also have special circumstances attached to its use, such as, perhaps, development only on a large scale in remote regions at a very high load factor. Our main source of both kilowatts and kilowatt-hours must, however, continue to be coal, whose use we can hope to improve by a further increase in operational economy and by limiting, where possible, transport of this fuel particularly by rail." Referring further to the gas-turbine, Mr. Haldane stated that several large gas-turbine sets of the order of $15,000-\mathrm{kW}$. capacity were at present under construction for use as peak-load plant. It might seem surprising that active consideration was being given to the possible large-scale use of wind power. "The renewed interest in the subject is due mainly to three factors : the existence of extensive grid systems into which intermittent supplies of energy, wherever produced, can be fed; the increased knowledge of aerodynamics; and the shortage of coal." The western shores of the British Isles are well suited to the large-scale development of wind power, and this source of energy deserves more attention than it has received in the past.

Referring to the siting of generating stations, Mr. Haldane said that there were, broadly speaking, three choices : at the load centre, at or near the pithead, or on an estuary site to which coal could be delivered by sea. Estuary sites far removed from the load centre were unlikely to compare favourably with generation at or near the pithead. An economic comparison relating to the London area showed that, once all the available estuary sites had been used, it would be advantageous to place the bulk of future generating stations near the coalfields, with highvoltage transmission to the load centre. Peak-load plant at the load centre might well consist largely of gas-turbines.

Second only in importance to the actual generation of the required amount of electric power came the provision of adequate transmission and intercon. nexion facilities. This function had been served in Great Britain up to the present by the $132-\mathrm{kV}$. grid; but consideration had been given to the desirability of providing an additional national busbar operating at a higher voltage. We were about to experiment with the use of $275 \mathrm{kV}$., which was regarded as adequate for the distances over which we had to transmit and was, incidentally, considered to be the highest voltage for which underground cables could be built at the present time. The highest voltage A.c. system in Europe was at present under construction in Sweden, where a large block of power would be transmitted a distance of about 600 miles at $380 \mathrm{kV}$. "It may well be desirable," said Mr. Haldane, "to proceed as soon as possible with the construction of such a very high voltage system superimposed on the existing $132 \mathrm{kV}$. grid."

Turning to the power problems of Western Europe, which are even more acute than those of Great Britain, Mr. Haldane showed on a map the distribution of energy resources. It had long been hoped, he said, that some day all the Western European countries would be interconnected so as to make better use of the available resources. "Technically it should be possible to have high capacity interconnexion extending eventually from Scandinavia in the north to France in the south, with further interconnexion to Austria, Switzerland and Italy. Economically it seems likely that this would be highly beneficial. In fact, few measures could be expected to be more beneficial to European economic life than such integration of power resources, meeting as it would one of the most urgent of Europe's problems and helping towards unification." In this connexion, the question arose of the desirability of a connexion. between the British system and that of the Continent. Technically, an interconnecting link between, say, London and Paris by high-voltage cable across the Channel appeared practicable. The question was whether the expenditure would be justified by saving in plant and interchange of energy.

The second part of Mr. Haldane's address was concerned with the philosophical implications of the 
activities of the engineer and the reaction of presentday conditions on his outlook. "As engineers concerned with applied science," said Mr. Haldane, "we occupy a position intermediate between that of pure science and that of the branches of knowledge concerned with human affairs. We are very definitely concerned both with the advancement of scientific knowledge and with the problem of how this knowledge can best be applied to meet human needs. The latter function makes it particularly important that the general educational background of engineering training should be as wide as possible and should not exclude those branches of knowledge generally known as the humanities.

"The present difficulties due to the huge content of knowledge and consequent tendency towards excessive specialization have led to the disappearance at an early stage in education of any general study of religion or philosophy, so that at the age when young people are becoming able to think on such subjects the great majority proceed to concentrate on mastering the means of life and remain indifferent to, and almost oblivious of, its ends.

"Future generations may well be amazed at our acceptance of such a state of affairs, the existence of which I feel to be one of the strongest arguments in favour of the higher education of engineers being centred in the universities rather than in mono-technic colleges. Although even in the best of our universities there may be too much concentration on means and too little thought about ends, the engineering undergraduate does at least get and give the immense advantage of mixing with those who are studying totally different branches of knowledge. The whole atmosphere of a university engineering education can be influenced by contacts with the other faculties, including the humanities, and consequently study can be on a much broader basis than is possible in colleges or institutions dealing with one subject or group of subjects."

In summing up, Mr. Haldane remarked, "In providing the conditions in which the things of the spirit can come to full fruition we undertake a vital as well as a noble task in which we can have the utmost pride. But let us fully understand the nature of our task, and let us spend more time than we now do in considering the ends to which our work is directed."

\section{MODERN DEVELOPMENTS IN FORESTRY}

$\mathrm{I}^{\mathrm{N}}$

Forestry Abstracts (Commonwealth Forestry 1 Bureau, vol. 10, No. 1 Abstracts (1)-(849), September 1948, Commonwealth Forestry Bureau, Oxford), Mr. J. J. MacGregor, of the Imperial Forestry Institute, Oxford, has an interesting paper on "Some Improved Techniques in Nurseries and on Planting Sites". There are many influences, he says, compelling foresters all over the world to revise time-worn practices. These influences are part of the general economic environment in which rising wages and relative shortages of labour are, perhaps, most significant. They have directly stimulated the search for more economic methods, machines and techniques. In a general way, current and recent developments have proceeded along the two main lines of 'rationalization' and the application of new techniques to specific operations. The latter, which includes the adoption of mechanization, improved processes with new tools and new treatments, forms the basis of the article.

In using the term 'rationalization' the author means it to be applied to the administration of staff, the training of subordinate workers, housing and amenities, the execution and close inspection of all work, and the provision of tools ; on this last point of tools one might add that, until recently in ordinary forest work, they were few, simple and no different from those in existence during what may be called the pre-mechanized times. In the modern study of these methods Sweden has given the lead and has been in the position, during the past ten years, when so many were otherwise engaged, to make considerable progress; and mention must be made of Swedish reorganisation of piece-work rates, which require to be both flexible and easily understood. Both in North America and in Germany forestry experts have been making similar studies. One form of 'rationalization' has been the suggested centralization of forest nurseries, since it is held, and rightly so, that the efficient raising of large stocks requires highly skilled and experienced supervision. Whether, however, the small nursery on the private estate should be regarded as obsolete is a matter which is open to considerable argument. The big battalions are by no means the safest in a matter of this kind, for many reasons.

On the side of technical mechanical developments, North America takes the lead. In agriculture, the application of labour-saving devices has gone a long way, and a few have been adapted for forestry purposes. But it is felt that special investigations, which are indeed being carried out by those conversant with forest nursery and other wider forestry problems, will have a greater chance of giving the forester new mechanical implements suitable to his particular type of work. The article also deals with the transfer of planting stock (storage and packing), preparation of sites, stump removal, plough and cultivators (the Forestry Commission has had a considerable success based on experiments with heavy ploughs), sowing and planting, planting methods and machines.

\section{LABORATORY GLASSWARE PRODUCTION}

$T$ THE expression 'E-MIL' may not be quite so well known as some others which have become quite commonplace; but it is likely to become a mark of quality standard in future. Messrs. H. J. Elliott, Ltd., Treforest Trading Estate, Nr. Ponty. pridd, Glam., whose trade mark it is, already enjoy a reputation for high-quality glassware for quantitative work; but they laudably seek to enhance that reputation by aiming at still higher standards and by offering unconditional guarantees concerning their products, as well as improvements in the character and packaging of the articles.

In the first place, their volumetric glassware will be designated ' $\mathbf{E}-\mathrm{Mil}$ Green Line' in the case of that which complies with National Physical Laboratory grade $A$ specifications, and 'E-Mil Gold Line' for that of the grade $B$ standard, the graduations of these varieties being filled respectively with insoluble green and yellow enamels. The pigments appear to be 